\title{
METHODOLOGICAL PROVISIONS ON THE PERFORMANCE EVALUATION OF AGRARIAN PRODUCERS AND THEIR COOPERATIVE ASSOCIATIONS IN THE PRODUCTION AND SUPPLY CHAIN
}

\author{
Oksana Nikishyna', Svitlana Bondarenko², Oksana Zerkina ${ }^{3}$
}

\begin{abstract}
The purpose of the article is to develop methodological provisions on performance evaluation of agrarian producers and their cooperative associations in production and supply chain on the basis of updated reproduction approach that is based on the use of net value added indicator. The research methodology is to conduct a critical analysis of existing scientific approaches to the assessment of value added; substantiate components of net value added; develop a structural scheme of methodological provisions in the duality of conceptual and methodological bases; substantiate a four-level system of estimating indicators using the net value added indicator; determine the possibilities and advantages of author's methodological provisions. Results. The authors prove the expediency of using the net value added indicator to assess the efficiency of both production and supply chains, as well as producers and their cooperative formations that are non-profit organizations. The components of net value added, which include wages, profit, and specific expenses of business entities in terms of the parts of the production and supply chain, are substantiated. The authors proposed a structural scheme of methodological provisions that united the conceptual and methodological bases, defined the main principles of evaluation: objectivity and accuracy, systemacity and complexity, efficiency, purposefulness, the priority of economic interests of the state (macrolevel). A four-level system of indicators is developed for estimating volumes and dynamics of net value added, reproductive product profitability, the structure of net value added, the efficiency of material and labour resources use. Practical implications. Methodological provisions can be used by commodity producers and their associations to assess the efficiency of operation in the production and supply chain, justifying the feasibility of establishing a cooperative in the region. Also, the results of the analysis can be used by the state authorities during the definition of "gaps" in the chain and the justification of methods of selective regulation for its balanced development. Value/originality. Methodological provisions developed by the authors form the analytical foundation for making managerial decisions both at the micro level (producers, cooperatives) and meso and macro levels (regional and state authorities).
\end{abstract}

Key words: agrarian producers, cooperatives, production and supply chain, efficiency.

JEL Classification: L10, L22, L50

\section{Introduction}

In a dynamic market, the realization of the potential of farms and private households that form the individual sector of the agrarian market, specialize in the production of low-income, labour-intensive but socially significant products, envisages the creation and development of cooperative production and supply chains (hereinafter - the PSC). Such chains combine commodity flows of agricultural cooperatives, allowing their members, including individual farms, to increase the value added of products, expanding their presence from one agrarian link to several links of the PSC (storage, processing, sales of products), to reduce logistics costs, to increase the efficiency of small business entities.

Justification of the directions and mechanisms of state support for the creation and development of cooperative

\footnotetext{
Corresponding author:

${ }^{1}$ Institute for Market Problems and Economic \& Ecological Research of NAS of Ukraine, Ukraine.

E-mail: ksenkych@gmail.com

ORCID: http://orcid.org/0000-0002-7172-3551

${ }^{2}$ Institute for Market Problems and Economic \& Ecological Research of NAS of Ukraine, Ukraine.

E-mail: lana.bond@ukr.net

ORCID: http://orcid.org/0000-0002-1687-1172

${ }^{3}$ International Humanitarian University, Ukraine.

E-mail: sir79@ukr.net

ORCID: http://orcid.org/0000-0001-5148-4189
} 
PSC in Ukraine necessitates the development of methodological support for assessing the performance of such chain organizations at the meso and macro levels. At the same time, it is important for members of agricultural cooperatives to evaluate the efficiency of the activity of a separate association (micro level). Given its social orientation and non-profit status, the use of profit as the main performance indicator, unlike enterprises of other forms of management, is not feasible. Thus, there is a need to change the main benchmark of the activity of cooperatives, which allows assessing the degree of realization of economic interests as of individual households - members of the cooperative, so of the state. In our view, such a benchmark is the value added indicator (hereinafter referred to as VA), which is a universal criterion for evaluating the efficiency of systems functioning at micro, meso, and macro levels.

\section{Scientific approaches to the assessment of added value}

In economic theory, there are four scientific approaches to the interpretation of the essence, nature, and methods of calculating the value added: (1) reproductive; (2) statistical; (3) accounting; (4) logistics. The basis of the reproductive approach was developed by K. Marx (Marx, 1978). According to his theory, the newly created value added includes the amount of remuneration of workers who directly create a new value and the profit of enterprise owners.

The statistical approach reflects the features of the macroeconomic accounting of the VA based on the system of national accounts. The State Statistics Service of Ukraine defines gross value added as the difference between the issue and intermediate consumption; by type of economic activity, gross value added is calculated as the sum of wages of hired workers, other taxes, except for other subsidies associated with production, and gross profit (mixed income). The term "gross" means that VA includes the amount of fixed capital consumption (depreciation). In the interpretation of the "value added" and "intermediate consumption" indicators in the context of the classical economic theory, depreciation is an element of the latter (Bratenkova, 2013).

If by the statistical approach gross value added is identified with the income generated by a certain type of economic activity in the total GDP, then the added value by the accounting approach is estimated from the point of view of the material carrier of this quantity, that is, the concrete product. In the accounting, VA of goods is calculated as the difference between the proceeds from the sale of the goods and the cost of the raw materials, supplies, and services purchased on the basis of the cost price of the products. In research, the methodology of accounting approach is used to analyse the VA of certain goods. By the logistic approach, the added value serves as a measure of the process of forming value, which purpose is to offer the client tangible utility (Hirna, Hlynskyi, Kobyliukh, 2012).

\section{Essence and components of net value added}

We suggest using an indicator of the added value of goods (services) for the analytical basis for constructing methodological provisions on the performance evaluation of agricultural producers and their cooperative associations in the PSC. In economic theory, there is no single approach to the definition of content and components of value added. The modern encyclopaedia treats VA (value added by processing) as the value of the sold product less the cost of materials purchased and used for its production. VA equals revenues, including wages, lease payment, rent, bank interest, profits, and depreciation; in many developed countries, it serves as the basis for indirect taxation. Another approach to the interpretation of the essence of value added is found in the economic dictionary: the value that is created in the production process at this enterprise and reflects its real contribution to the creation of the value of a specific product. In our view, this approach most deeply determines the nature of value added, hence it can be used for its interpretation at the chain level.

Thus, value added is the value created in the process of production of goods (provision of services) by economic entities of a certain level of the production and supply chain, which reflects the real contribution of this link in the formation of the value chain. VA reflects the value added for the product when it passes through the chain from the original manufacturer to the end user. It is intended to measure the value created by economic entities on a certain link of the PSC. Total value added in the chain will include the sum of all newly created values of links; their number depends on the specifics of reproducing the product in certain geographical boundaries.

In domestic and foreign science and practice, there is no single approach to the definition of resource components of VA. In our opinion, in this aspect, two main approaches can be distinguished. The supporters of the first approach (Hirna, Hlynskyi, Kobyliukh, 2012; Ivanenko, 2012), along with the income and wages of employees, include the depreciation of non-current assets in value added. The supporters of the second approach (Bulyga, Kokhno, 2007; Bratenkova, 2013) consider salaries and profits as the main components of VA. In the classical economic theory, depreciation of non-current assets is a component of intermediate consumption. In terms of capital turnover, depreciation can be interpreted as consumption in a certain operating cycle of a part of the past materialised work (in the form of objects of fixed assets). In order to assess the enterprise's results, the VA indicator is more objective excluding the 
value of consumption of fixed capital. It is this indicator that reflects the real volume of the newly created value by the market participant, therefore, is more informative for analysis and management (Bratenkova, 2013).

We support the second approach and suggest using the net value added indicator in order to construct a system of indicators on its basis for assessing the performance of agricultural producers and their cooperative associations in the PSC. The term "net" means that the VA does not include depreciation of non-current assets. At the same time, its component is the specific costs that reflect the peculiarities of the reproduction processes of certain parts of the PSC and are characteristic only for them. For example, for the breeding sector, it is expedient to include the costs of cleaning and sorting seeds for the specific costs, for agrarian one - the lease of land plots. Thus, the formula for the calculation of net
VA in the links of the production and supply chain will have the following form:

$$
A B_{\mathbf{Y}}=3 \Pi+\Pi+B_{C} \text {, }
$$

where $\mathbf{A} \mathbf{B}_{\mathbf{Y}}$ - net value added, created by the PSC link; $\Pi$ - a profit of business entities of a certain chain;

$\mathbf{3 \Pi}$ - the wage of employees at enterprises of the link; $\mathbf{B}_{\mathbf{C}}-$ specific expenses of subjects of a certain chain link.

\section{Structural scheme of methodical provisions}

Methodological provisions on the performance evaluation of agrarian producers and their cooperative associations in the production and supply chain, developed by the authors, combine the conceptual and methodological bases, the components of which are shown in Fig. 1. The conceptual basis consists of theories of resources reproduction and the formation of a value

\begin{tabular}{|c|c|}
\hline & $\begin{array}{l}\text { Conceptualbasis } \\
\text { theory of the reproduction of resources, the formation of a value chain }\end{array}$ \\
\hline $\begin{array}{r}\text { multilevel assessment of the } \mathrm{fc} \\
\text { for making }\end{array}$ & $\begin{array}{l}\text { The purpose of methodological provisions: } \\
\text { ormation of net value added by the links of the production and supply chain as a methodical basis } \\
\text { managerial decisions to ensure the balanced development of cooperative PSCs }\end{array}$ \\
\hline $\begin{array}{l}\text { 1. Analysis of the dynamics of chang } \\
\text { 2. Analysis of the structure of net val } \\
\text { 3. Evaluating the effectiveness of usir } \\
\text { 4. Determination of flow "gaps" in th } \\
\text { 5. Qualitative assessment of the analy } \\
\text { 6. Forecasting of development of pro }\end{array}$ & $\begin{array}{l}\text { Tasks of methodological provisions: } \\
\text { es in net value added and performance indicators in nominal and real terms; } \\
\text { ue added in the statics and dynamics behind chain links; } \\
\text { ag resources in the system; } \\
\text { e PSC according to the evaluation results; } \\
\text { ysis results as the basis for making managerial decisions at micro and macro levels; } \\
\text { cesses and performance indicators of PSC links' subjects. }\end{array}$ \\
\hline Principles of evaluat & ting the performance of agricultural producers and their cooperative associations in the PSC \\
\hline 1. Objectivity and accuracy & $\begin{array}{l}\text { The information base for evaluation should be reliable, and its results should be based on accurate } \\
\text { analytical calculations }\end{array}$ \\
\hline 2. Systemic and complexity & $\begin{array}{l}\text { Performance evaluation of the PSC as a dynamic system is carried out taking into account all internal } \\
\text { and external connections between the elements and their interdependence }\end{array}$ \\
\hline 3. Efficiency & $\begin{array}{l}\text { The evaluation results should have an applied value, serve as a basis for taking measures for levelling } \\
\text { (reducing) flow "gaps" in the chain }\end{array}$ \\
\hline 4. Purposefulness & Target definition of flow "gaps" in the PSC, which are a source of the disintegration of system elements \\
\hline $\begin{array}{l}\text { 5. Priority of economic interests of the } \\
\text { state (macro level) }\end{array}$ & $\begin{array}{l}\text { Performance evaluation of the PSC is carried out not from the standpoint of economic interests } \\
\text { of individual market players but the state as a carrier of the interests of society; This principle is also } \\
\text { the key to making managerial decisions about the selective influence on the flow "gaps" in the chain }\end{array}$ \\
\hline & Methodologicalbasis \\
\hline $\begin{array}{l}\text { Methodological provisions } \\
\text { 1. Definition of the commodity, territor } \\
\text { 2. Performance evaluation of producers } \\
\text { 2.1. Estimation of volumes and dyna } \\
\text { 2.2. Evaluation of reproductive prod } \\
\text { 2.3. Estimation of the structure of ne } \\
\text { 2.4. Assessment of the efficiency of } t \\
\text { 3. PSC diagnosis, qualitative analysis of } c\end{array}$ & $\begin{array}{l}\text { on the performance evaluation of agricultural producers and their associations in the PSC. } \\
\qquad \text { Main stages of evaluation: } \\
\text { ial, and time limits of the market for certain agricultural products. } \\
\text { in the PSC using a set of indicators: } \\
\text { mics of net value added } \\
\text { uct profitability } \\
\text { t value added } \\
\text { he use of material and labour resources (by net added value) } \\
\text { ause-and-effect relationships that determine flow processes in the chain; projected scenarios for the PSC development. }\end{array}$ \\
\hline Priorities of the national coo & perative policy, strategic guidelines for the development of agrarian cooperation in an open economy \\
\hline $\begin{array}{l}\text { 1. Regulatory 3. Administrative } \\
\text { 2. Financial and economic } 4 \text {. Organis }\end{array}$ & $\begin{array}{l}\text { Methods of state regulation of the development of cooperative PSC: } \\
\text { sational }\end{array}$ \\
\hline
\end{tabular}

Figure 1. Structural scheme of methodical provisions on the performance evaluation of agrarian producers and their cooperative associations in the production and supply chain

Source: the author's development 
chain. The main goal of the methodological provisions is the multilevel assessment of the formation of net value added by the links of the production and supply chain as a methodical basis for making management decisions in order to ensure the PSC balanced development. It is about managerial decisions both at the micro level (economic entities and their associations) and at the macro level (state authorities). Therefore, the main goal of the provisions organically combines the economic interests of agricultural producers and the state in the aspect of the PSC balanced development, in particular, cooperative ones.

The production and logistics chain has three fundamental properties: dynamism, proportionality, and stability. To reflect these properties, the PSC analysis in general and its links in particular should be aimed at solving three conceptual tasks: (1) analysis of dynamic trends; (2) analysis of the proportionality of development; (3) stability and efficiency analysis. The assigned tasks of the methodical provisions are oriented on the assessment of the principle properties of the PSC, as well as the definition of "gaps", qualitative evaluation and forecasting of the development of the chain and its components (see Figure 1).

The methodical basis includes methodological provisions for assessing the performance of agricultural producers and their associations in the PSC, diagnosing and forecasting the main parameters of the chain development as a basis for choosing the methods and measures of state regulation, coordinated with the priorities of national policy, in particular, cooperative (see Figure 1). Let us consider in more detail the estimated component of the methodological provisions, which involves the design of certain groups of analytical indicators.

\section{The system of evaluation indicators}

Since the basis of the functioning of the PSC is the movement and transformation of the commodity flow, the first stage of the methodology is to determine the commodity, territorial, and time boundaries of the market for a certain agrarian product. The second stage involves the calculation of four groups of analytical indicators (see Figure 1). Characteristics of the developed four-level system of indicators for assessing the performance of agricultural producers and their cooperative associations in the PSC and the formulas for calculating the indicators are given in Table 1.

The first level of the valuation system involves assessing volumes and dynamics of net value added in two dimensions: nominal and real. To switch from the nominal measurement of the indicator (in current prices) to the real one, it is necessary to recalculate its value in the dollar equivalent. Use of real indicators in the estimation allows, firstly, increasing the objectivity of the analysis, neutralizing the effect of the price inflationary movement, and secondly, carrying out a comparative analysis of the growth rates of nominal and real values and determining the latent trends in the dynamics of their changes. It should be noted that real indicators can be used not only in the analysis of net VA but also additional indicators, in particular, output and cost of production, profit, productivity, etc. (see Table 1).

The indicator of the share of net VA in output, which is calculated both for the individual producer and the PSC link, in the theory of integration analysis serves as one of the classic indicators for measuring and monitoring vertical integration at the level of economic entities. This index varies from 0 to 1 , where 1 represents the maximum level of integration.

The ratio of growth rates (indices) of net VA and production output, developed by the author, characterizes in relative terms the dynamics of changes in the indicator of the share of the newly created value in the output and simultaneously determines the factors of its growth (see Table 1). Indicators of the share of net VA in the output and the ratio of these values are among the indicators of the proportionality of the development of a particular system of micro or macro level. The share of proportion indicators, represented by ratios and shares of components of net value added, occupies a significant place in the developed evaluation system. Their analysis in statics (during the reporting year) and in dynamics (for several years) will allow determining trends of dynamic changes, estimating structural shifts and regional differences in the shares of performance indicators.

The second level of the valuation system is oriented towards assessing the reproductive profitability and classical profitability of products of business entities of a certain link of the PSC, reflecting the resulting approach to the evaluation of the efficiency of microsystems. Reproductive profitability determines the amount of net VA per $1 \mathrm{UAH}$ of costs of products (services) of a certain chain link (see Table 1). The level of reproductive profitability, as a rule, is higher than the traditional indicator of product profitability. In terms of loss-making nature of the production and the negative value of product profitability, the indicator of reproductive profitability is positive, reflecting the newly created value, represented, first of all, by social component - wage of employees. This indicator is a practical embodiment of the estimated function of added value, a measure of the degree of realization of the economic interests of workers, economic entities, and the state. Changing the target orientation of microsystems (from the increase in profits to value added) allows hired employees to be regarded as the intellectual capital of enterprises which role in the era of intellectualization and innovation of business activity is increasing (Hridchina, 2013).

The second-level elements of the system include two coefficients of the ratio: (1) the growth rate of net VA 
Vol. 4, No. 5, 2018

Table 1

The system of indicators for evaluating the performance of agricultural producers and their cooperative associations in the production and supply chain*

\begin{tabular}{|c|c|c|c|}
\hline Indicators & Characteristics & Formula of calculation & Normative value \\
\hline 1 & 2 & 3 & 4 \\
\hline \multicolumn{4}{|c|}{ 1. Estimation of volumes and dynamics of net value added } \\
\hline 1.1. Net value added $\left(\mathbf{A} \mathbf{B}_{\mathbf{q}}\right)$ & $\begin{array}{l}\text { Displays the real contribution of the } \\
\text { actors of a certain link in the creation of } \\
\text { added value in the chain }\end{array}$ & $\begin{array}{l}\mathbf{A} \mathbf{B}_{\mathbf{Y}}=\mathbf{3} \boldsymbol{\Pi}+\boldsymbol{\Pi}+\mathbf{B}_{\mathrm{C}} \text {, } \\
\text { where } \mathbf{3} \boldsymbol{\Pi}-\text { the wage of employees of } \\
\text { the link; } \boldsymbol{\Pi} \text { - a profit of business entities; } \\
\mathbf{B}_{\mathbf{C}}-\text { specific expenses of the subjects of } \\
\text { a certain link }\end{array}$ & Growth in dynamics \\
\hline $\begin{array}{l}\text { 1.2. Share of net VA in } \\
\text { production output }\left(\mathbf{Y}_{\mathrm{AB \Psi}}\right)\end{array}$ & $\begin{array}{l}\text { The share of net VA in the output of the } \\
\text { entities of a certain link of the PSC }\end{array}$ & $\begin{array}{l}\mathbf{U}_{\mathrm{AB} \mathbf{Y}}=\mathbf{A} \mathbf{B}_{\mathbf{Y}} / \mathbf{B} \text {, } \\
\text { where } \mathbf{B} \text { - production output (in value } \\
\text { terms) of the PSC link }\end{array}$ & Growth in dynamics \\
\hline $\begin{array}{l}\text { 1.3. Ratio of the growth rate of } \\
A B Y \text { and output }\left(\mathbf{K}_{\mathbf{B}}\right)^{* *}\end{array}$ & $\begin{array}{l}\text { The ratio of the index of net VA to the } \\
\text { output index of the entities of a certain } \\
\text { link of the PSC }\end{array}$ & $\begin{array}{l}\mathbf{K B}=\mathbf{I}_{\mathbf{A B q}_{\mathbf{Y}}} / \mathbf{I}_{\mathbf{B}}, \\
\text { where } \mathbf{I}_{\mathbf{A B}_{\mathbf{B}}}-\text { the growth rate of net VA; } \\
\mathbf{I}_{\mathbf{B}}-\text { the growth rate of output (in value } \\
\text { terms) in view of chain links }\end{array}$ & More than 1 \\
\hline \multicolumn{4}{|c|}{ 2. Evaluation of reproductive product profitability } \\
\hline $\begin{array}{l}\text { 2.1. Reproductive product } \\
\text { profitability (PB) }\end{array}$ & $\begin{array}{l}\text { The volume of net VA per } 1 \text { UAH } \\
\text { of costs of production of products } \\
\text { (services) of a certain link of the PSC }\end{array}$ & $\begin{array}{l}\mathbf{P B}=\mathbf{A} \mathbf{B}_{\mathbf{Y}} / \mathbf{B}, \\
\text { where } \mathbf{B}-\text { expenses for the production } \\
\text { of products (services) of a certain link of } \\
\text { the production and supply chain }\end{array}$ & Growth in dynamics \\
\hline $\begin{array}{l}\text { 2.2. Ratio of the growth } \\
\text { rate of } A B Y \text { and the cost of } \\
\text { production }\left(\mathbf{K}_{\mathbf{C}}\right)^{* *}\end{array}$ & $\begin{array}{l}\text { The ratio of the net VA index to the } \\
\text { production cost index of the entities of a } \\
\text { certain link of the PSC }\end{array}$ & $\begin{array}{l}\mathbf{K}_{\mathbf{C}}=\mathbf{I}_{\mathrm{AB \Psi}} / \mathbf{I}_{\mathbf{C}} \text {, } \\
\text { where } \mathbf{I}_{\mathbf{C}}-\text { the growth rate of the cost of } \\
\text { production in view of chain links }\end{array}$ & More than 1 \\
\hline 2.3. Product profitability $\left(\mathbf{P}_{\Pi}\right)$ & $\begin{array}{l}\text { The volume of profit per } 1 \text { UAH of costs } \\
\text { of subjects of the PSC link }\end{array}$ & $\begin{array}{l}\mathbf{P}=\boldsymbol{\Pi} / \mathbf{B} \\
\text { where } \boldsymbol{\Pi} \text { - a profit of the entities } \\
\text { of a certain link }\end{array}$ & Growth in dynamics \\
\hline $\begin{array}{l}\text { 2.4. Ratio of growth rates of } \Pi \\
\text { and production cost }\left(\mathbf{K}_{\Pi}\right)^{* *}\end{array}$ & $\begin{array}{l}\text { The ratio of the index of profit to the } \\
\text { index of the production cost of entities } \\
\text { of a certain link of the PSC }\end{array}$ & $\begin{array}{l}\mathbf{K}_{\Pi}=\mathbf{I}_{\Pi} / \mathbf{I}_{\mathbf{C}} \text {, } \\
\text { where } \mathbf{I}_{\Pi}-\text { the growth rate of profit of } \\
\text { entities in view of chain links }\end{array}$ & More than 1 \\
\hline \multicolumn{4}{|c|}{ 3. Estimation of the structure of net value added } \\
\hline 3.1. Share of wages $(\mathbf{4} 3 \Pi)$ & $\begin{array}{l}\text { The amount of labour costs to create } 1 \\
\text { UAH of net VA }\end{array}$ & $\mathbf{Y}_{3 \Pi}=3 \Pi / \mathbf{A} \mathbf{B}_{\mathbf{Y}}$ & \multirow{3}{*}{$\begin{array}{l}\text { Optimization of } \\
\text { shares of components } \\
\text { of net VA subject } \\
\text { to the specificity } \\
\text { of reproduction } \\
\text { processes }\end{array}$} \\
\hline 3.2. Share of profit (بП) & $\begin{array}{l}\text { The share of profit in net VA created by } \\
\text { the entities of a certain link of the PSC }\end{array}$ & $\mathbf{Y}_{\Pi}=\boldsymbol{\Pi} / \mathbf{A} \mathbf{B}_{\mathbf{Y}}$ & \\
\hline $\begin{array}{l}\text { 3.3. Share of specific expenses } \\
\text { (पBC) }\end{array}$ & $\begin{array}{l}\text { The share of specific expenses in net VA } \\
\text { of the entities of the link }\end{array}$ & $\mathbf{Y}_{\Pi}=\mathbf{B}_{\mathrm{C}} / \mathbf{A} \mathbf{B}_{\mathbf{Y}}$ & \\
\hline \multicolumn{4}{|c|}{ 4. Assessment of the efficiency of material and labour resources use (by net added value) } \\
\hline $\begin{array}{l}\text { 4.1. Return on assets ratio } \\
\left(\boldsymbol{\Phi}_{\mathbf{B}}\right)\end{array}$ & $\begin{array}{l}\text { Value of net VA created using } 1 \mathrm{UAH} \text { of } \\
\text { fixed assets }\end{array}$ & $\begin{array}{l}\Phi_{\mathbf{B}}=\mathbf{A} \mathbf{B}_{\mathbf{Y}} / \mathbf{O 3}, \\
\text { where } \mathbf{O 3} \text { - the value of fixed assets of } \\
\text { entities of a certain link of the PSC }\end{array}$ & Growth in dynamics \\
\hline 4.2. Material return $(\mathbf{M B})$ & $\begin{array}{l}\text { Autonomy of labour; Value of net VA } \\
\text { per } 1 \text { UAH of materialized labour }\end{array}$ & $\begin{array}{l}\mathbf{M B}=\mathbf{A} \mathbf{B}_{\mathbf{Y}} / \mathbf{M B}, \\
\text { where } \mathbf{M B} \text { - the value of material costs } \\
\text { of subjects of a certain link of the PSC }\end{array}$ & Growth in dynamics \\
\hline $\begin{array}{l}\text { 4.3. Ratio of growth rates } \\
\text { of } A B_{\mathbf{Y}} \text { and material costs } \\
(\mathbf{K M})^{* *}\end{array}$ & $\begin{array}{l}\text { The ratio of the net VA index to the } \\
\text { material cost index of entities of a } \\
\text { certain link of the PSC }\end{array}$ & $\begin{array}{l}\mathbf{K M}=\mathbf{I}_{\mathbf{A B}} / \mathbf{I}_{\mathbf{M B}} \\
\text { where } \mathbf{I}_{\mathbf{M B}}-\text { the growth rate of material } \\
\text { costs of entities in view of chain links }\end{array}$ & More than 1 \\
\hline $\begin{array}{l}\text { 4.4. Materials-output ratio } \\
\left(\mathbf{M}_{\mathbf{E}}\right)\end{array}$ & $\begin{array}{l}\text { Dependence of the production process } \\
\text { on external sources; the amount of the } \\
\text { transferred value for the production of } 1 \\
\text { UAH of net VA }\end{array}$ & $\mathbf{M}_{\epsilon}=\mathbf{M B} / \mathbf{A} \mathbf{B}_{\mathbf{Y}}$ & Decrease in dynamics \\
\hline $\begin{array}{l}\text { 4.4.1. Raw materials output } \\
\text { ratio }\left(\mathbf{C}_{\epsilon}\right) \\
\text { 4.4.2. Fuel output ratio }\left(\boldsymbol{\Pi}_{\epsilon}\right) \\
\text { 4.4.3. Energy-output ratio }\left(\mathbf{E}_{\epsilon}\right)\end{array}$ & $\begin{array}{l}\text { Expenditures of certain types of } \\
\text { materials (raw materials, fuel, and } \\
\text { electricity) per } 1 \mathrm{UAH} \text { of } A B Y \text { in view } \\
\text { of chain links }\end{array}$ & $\begin{array}{l}\mathbf{C}_{\boldsymbol{E}}=\mathbf{C B} / \mathbf{A} \mathbf{B}_{\mathbf{Y}} ; \\
\boldsymbol{\Pi}_{\mathbf{E}}=\mathbf{\Pi B} / \mathbf{A} \mathbf{B}_{\mathbf{Y}} ; \\
\mathbf{E}_{\mathbf{E}}=\mathbf{E B} / \mathbf{A} \mathbf{B}_{\mathbf{\Psi}} \text {, where } \mathbf{C B}, \boldsymbol{\Pi B}, \mathbf{E B} \\
\text { - the value of raw materials, fuel, and } \\
\text { energy costs of entities of the PSC links }\end{array}$ & Decrease in dynamics \\
\hline 4.5. Labour productivity (ПП) & $\begin{array}{l}\text { Value of net VA created by the employee } \\
\text { during the production process }\end{array}$ & $\begin{array}{l}\mathbf{\Pi \Pi}=\mathbf{A} \mathbf{B}_{\mathbf{Y}} / \mathbf{Y} \text {, where } \mathbf{Y} \text { - the number } \\
\text { of employees of entities of a certain link }\end{array}$ & Growth in dynamics \\
\hline
\end{tabular}

* Developed by the authors using sources (Ivanenko, 2012; Savitskaya, 2002);

** Indicator is proposed by the authors. 
and the cost of production, which allows determining the dynamics of reproductive product profitability and the factors of its changes; (2) the growth rate of profit and production cost to assess the dynamic changes of the traditional indicator of product profitability (see Table 1). Calculated ratios can be compared by different links of the PSC. One should note the expediency of calculating indices of cost indicators (output, cost of production, profit) in nominal and real terms for their further comparison and analysis of the influence of the inflation factor on the profitability of agrarian producers and their cooperative associations.

Within the third level of the valuation system, an analysis of the component structure of net value added is provided (see Table 1). The indicator of the wage share determines the amount of labour costs to create $1 \mathrm{UAH}$ of net VA; in the theory of economic analysis, it is called the labour intensity of value added. An indicator of the share of profit determines the specific weight of operating profit in the value created by entities of a certain chain link. V. O. Ivanenko calls this indicator as the profitability of added value (Ivanenko, 2012). An indicator of the share of specific expenses characterizes, first of all, the size of land rent per $1 \mathrm{UAH}$ of newly created value by enterprises in the selection and agrarian link of the PSC; this indicator may be absent in other chain links.

The issue of the optimal structural relation of various resource components of net value added in economic theory is controversial. In general, the shares of the components are determined by the peculiarities of the reproduction process of a particular product. At the same time, the substantial dominance of certain components in the structure of the newly created value is evidence of structural imbalances and discrimination of economic interests of certain groups of participants in the reproduction process (enterprises, workers, consumers). A comparative analysis of the value added structure at micro, meso, and macro levels is intended to determine the unique proportions for economic systems of different hierarchical levels, common or different tendencies in their changes.

The fourth level of the evaluation system focuses on the analysis of the efficiency of material and labour resources, reflecting the resource approach to the evaluation of the effectiveness of microsystems, which involves the rational use of resources. The basis for calculating the main indicators of the efficiency of resources use - return on assets ratio, material return, materials-output ratio, and its private indicators, labour productivity - instead of gross or commodity output indicators commonly used in the economic analysis, is the net value added.

An indicator of return on assets ratio determines the amount of net VA created using $1 \mathrm{UAH}$ of fixed assets of entities of a certain level of the PSC (see Table 1). An indicator of material return shows the value of net
VA per 1 UAH of materialized (transferred) labour and characterizes the autonomy of labour. The dynamics of its changes and the effect of factors allow us to estimate the ratio of growth rates of net value added and material costs in view of links of the production and supply chain. Materials-output ratio (dependency ratio), calculated as the ratio of the materialised labour on net VA, characterizes the dependence of subjects of a certain link of the PSC on the external environment. Private indices of the materials-output ratio are raw materials, fuel, and energy output ratios (Savitskaya, 2002); they can be used to assess the economic effect of dematerialization in terms of links of the production and supply chain, which determines their practical significance and the feasibility of inclusion in the system.

An indicator of labour productivity characterizes the value of net added value created in the production process by one employee within the chain link. One should note the expediency of calculating this indicator in nominal and real terms in order to exclude the influence of the inflation factor and objective interpretation of the analysis results. In order to assess the resource use efficiency by links of the production and supply chain, dynamic and static coefficients of productivity of production factors are used. Static coefficients represent the ratio of the volume of net VA to the costs of certain types of production factors in the reported year. Dynamic indices are obtained by dividing the static coefficient for the reporting period by a similar ratio of the previous period; at the same time, the resulting dimensionless indicator reflects the change in productivity over time. Accordingly, the analysis of indicators of the fourth level of the system involves the calculation of both static and dynamic indicators in terms of links of the PSC.

The introduction of methodological provisions for evaluating the performance of agricultural producers and their cooperative associations in managerial practice requires the use of general and special methods. The general method of research is the dialectic method, which involves the study of all phenomena in interconnection and interdependence, as well as in the process of movement, change, and development. The special methods of studying the production and supply chain, given its complexity and versatility, include methods of economic analysis (statistical and economic-mathematical), economic-geographical, and sociological research. The applied implementation of the developed four-level system of indicators (see Table 1) involves the use of methods of comparative analysis (horizontal, vertical, interregional), index and balance methods, methods of mathematical analysis, etc.

Of particular importance in the study process is the balance method, which involves the creation of inter-link balances of net value added, reproductive profitability, material return, labour productivity, and other performance indicators. With such inter-link 
balances, one can evaluate and justify the optimal ratio between the PSC links, as well as determine the flow "gaps" in the chain. The balance method is appropriate to use on the third stage of evaluation during the diagnosis of the production and supply chain, qualitative analysis of causal relationships that determine the flow processes in the chain (see Figure 1). The results of qualitative analysis form a multidimensional analytical basis for modelling the forecast scenarios for the development of individual agricultural producers and their cooperative associations, as well as the PSC for a certain product.

\section{Possibilities and advantages of methodical provisions}

Users of methodological provisions can be producers and their cooperative and other integrated associations, as well as state and regional authorities. The use of methodological provisions by small and medium agricultural producers, as potential members of cooperative associations, will allow determining the dynamics of changes in the main performance indicators of their activities before and after cooperation, calculating the predictive values of these indicators as a justification of the economic feasibility of forming an agricultural cooperative in the region. The results of quantitative and qualitative analysis form the analytical foundation for choosing certain methods of state regulation, coordinated with the priorities of national policy, in particular, cooperative, the implementation of which corresponds to the strategies for the development of agrarian cooperation in an open economy (see Figure 1).

The unconditional advantages of the developed methodological provisions for evaluating the performance of agricultural producers and their cooperative associations in the production and supply chain should include the following:

1) multilevel estimation of the dynamics and structure of net VA by chain links, the formation of interlink balances of newly created value for analysis and substantiation of optimal proportions of the value chain;

2) the possibility of conducting a comparative analysis between different links of the PSC, which allows identifying the flow "gaps" that are the object of selective management influence;

3) the calculation of the main performance indicators in real and nominal terms in order to exclude the influence of the price inflationary movement and increase the objectivity of analytical calculations;

4) multi-dimensional analysis of the proportionality of the chain development by calculating the parameters of the structure in statics and dynamics for the determination of structural imbalances and deformations that hamper the system development;

5) assessment of the efficiency of material and labour resources use in micro and macro systems with the help of indicators developed on the basis of net VA, which allows ensuring the accuracy and reliability of the analysis;
6) high administrative capacity of the system of indicators, the possibility of their use as a scientific substantiation of managerial decisions;

7) the flexibility of the methodological provisions, their high adaptability to the new conditions of research, in particular, changes in the place of producers or their cooperative associations in the PSC, the modification of strategic management tasks, etc.

\section{Conclusions}

In the course of the study, the authors substantiated the components of net value added, proved the feasibility of using this indicator to evaluate the performance of agricultural cooperatives, which are non-profit socioeconomic institutions, in the production and supply chain. A structural scheme of methodological provisions in the duality of conceptual and methodological bases is developed, the purpose, tasks, and principles of evaluation are substantiated including the following: objectivity and accuracy, systemacity and complexity, efficiency, purposefulness, the priority of economic interests of the state (macrolevel). A system of indicators developed by the authors includes four groups of indicators for estimating volumes and dynamics of net VA, reproductive product profitability, the structure of net value added, the efficiency of material and labour resources use. The use of methodological provisions in comparative analysis of indicators of different links of the PSC allows identifying the flow "gaps" which are the object of selective managerial influence.

The scientific novelty of the research carried out is the improvement of the methodological provisions on the performance evaluation of agricultural producers and their cooperative associations in the production and supply chain, which in contrast to existing methodologies, are based on the four-level system of indicators constructed on the basis of the net value added index, provide for the calculation of performance indicators in nominal and real terms and ratios that allow determining the factors of influence on the dynamics of reproductive profitability indicators and material return. The theoretical significance of the research results is the development of methodological support for the performance evaluation of cooperative formations in the production and supply chain at micro and macro levels, and practical - in the possibility of using the author's methodological provisions by state and regional authorities, producers and their cooperative associations as an analytical basis for making managerial decisions.

Further research prospects in this scientific direction are to expand the system of valuation indicators constructed on the basis of the net value added index, as well as to use methodological provisions developed by the authors to evaluate the performance of not only agricultural but also industrial enterprises in the production and supply chain. 


\section{References:}

Bratenkova, T. M. (2013). Metodicheskie podkhody k opredeleniyu dobavlennoi stoimosti v aspekte izmereniya regionalnogo produkta [Methodical approaches to the definition of value added in the aspect of measuring the regional product]. Proceedings of the Belarusian State Technological University, 7, 13-15. (in Russian)

Bulyga, R., Kokhno, P. (2007). Dobavlennaya stoimost kak tselevoi kriterii [Added value as a target criterion]. Economist, 10, 68-76. (in Russian)

Hirna, O. B., Hlynskyi, N. Yu., Kobyliukh, O. Ia. (2012). Formuvannia dodanoi vartosti dlia kliienta v lantsiuhu postavok [Formation of value added for the customer in the supply chain]. Logistics: Theory and Practice, 1(2), 39-46. (in Ukrainian)

Hridchina, M. V. (2013). Pro dodanu vartist yak pokaznyk rezultativ diialnosti suchasnykh korporatsii [About value added as an indicator of performance of modern corporations]. Scientific works of the Interregional Academy of Personnel Management, 1(36), 126-129. (in Ukrainian)

Ivanenko, V. O. (2012). Dodana vartist yak obiekt analizu statystychnoi zvitnosti promyslovykh pidpryiemstv z vyrobnytstva produktsii [Added value as an object of analysis of statistical reporting of industrial enterprises of production]. Problems of the theory and methodology of accounting, control and analysis, 1(22), 122-130. (in Ukrainian) Marx, K. (1978). Kapital. Kritika politicheskoi ekonomii. Tom 1. [Capital. Criticism of political economy. Volume 1]. (I. I. Skvorcov - Stepanov, Trans). Moskva: Izdatelstvo politicheskoj literatury. (in Russian)

Savitskaya, G. V. (2002). Analiz khozyaistvennoi deyatelnosti predpriyatiya [Analysis of the economic activity of the enterprise]. Minsk: LLC «Novoe znanie». (in Russian) 